\title{
Competência de órgãos federais na persecução de infrações ambientais (penais ou administrativas) enquadradas na Lei 9.605 de 1998
}

O demasiado e complexo arcabouço legal brasileiro compromete o entendimento e operacionalização da ação e do processo administrativo e/ou penal sobre infratores ambientais. Neste sentido, o objetivo geral desta pesquisa foi o de descrever a competência dos órgãos federais na persecução de infrações ambientais (penais ou administrativas) enquadradas na Lei no 9.605/98, demonstrando os fluxos de trabalho dos órgãos envolvidos, através de levantamento tipológico funcionalista e fundamentação teórica pertinente, para dotar os operadores do Direito dos conhecimentos necessários para atuação nesta segmentação criminológica. Por fim, e então objeto maior deste estudo, tem-se clareza de que todos os órgãos policiais, sejam administrativos ou judiciários, nas esferas internacional, federal, estadual e/ou municipal, inclusive todas as pessoas, tem o dever de agir para combater os atos lesivos ao meio ambiente em sua mais ampla concepção. Tendo na esfera federal, objeto desta observação, o IBAMA, o ICMBIO, a Polícia Rodoviária Federal, e a Capitania dos Portos da Marinha do Brasil como agências federais administrativas, e a Polícia Federal como agência federal judiciária, todas aptas a isolada ou integradamente, oferecer denúncias e informações ao Ministério Público Estadual ou Federal, a depender das características da infração.

\section{Competence of federal agencies in the prosecution of environmental offenses (criminal or administrative) under Brazilian Law 9.605 of \\ 1998}

The overly complex Brazilian legal framework compromises the understanding and operationalization of the action and administrative and / or criminal proceedings against environmental violators. In this sense, the general objective of this research was to describe the competence of federal agencies in the prosecution of environmental infractions (criminal or administrative) framed by Law No. 9.605/98, demonstrating the workflows of the agencies involved, through a functionalist typological survey. pertinent theoretical foundation, to provide Law operators with the necessary knowledge to act in this criminological segmentation. Finally, and thus the main object of this study, it is clear that all police agencies, whether administrative or judicial, at the international, federal, state and / or municipal levels, including all persons, have a duty to act to combat acts harmful to the environment in their broadest conception. Having at the federal level, the object of this observation, IBAMA, ICMBIO, the Federal Highway Police, and the Brazilian Navy Port Authority as federal administrative agencies, and the Federal Police as a federal judicial agency, all fit alone or in full, offer complaints and information to the State or Federal Prosecution Service, depending on the characteristics of the violation.

Keywords: Environmental Law; Environmental Infractions; Law 9,605 / 98; Administrative Sanctions; Criminal Sanctions; Competence of Federal Agencies.

Topic: Direito Ambiental

Reviewed anonymously in the process of blind peer.
Received: 12/08/2019

Approved: 25/09/2019
Carlos Eduardo Silva (10)

Centro Universitário Estácio de Sergipe, Brasi

http://lattes.cnpq.br/3700554054159220

http://orcid.org/0000-0001-8358-0263

carlos.eduardo@cbpciencia.com.br

Sandro Luiz da Costa

Universidade Federal de Sergipe, Brasil

http://lattes.cnpq.br/7416946586434951

sandrolcosta@infonet.com.br
Referencing this:

SILVA, C. E.; COSTA, S. L.. Competência de órgãos federais na persecução de infrações ambientais (penais ou administrativas) enquadradas na Lei 9.605 de 1998. Scientiam Juris, v.7, n.1, p.11-25, 2019. DOI: http://doi.org/10.6008/CBPC2318-3039.2019.001.0002 


\section{INTRODUÇÃO}

Apesar dos dados alarmantes divulgados desde sempre sobre o cenário ambiental, seja por meio de mídias jornalísticas ou veículos de comunicação científicos, o que se sabe de certo é que os infratores ambientais seguem tranquilos destruindo o patrimônio difuso da sociedade, especialmente em países subdesenvolvidos. Neste sentido, o Direito, como ramo da ciência, não poderia ficar alheio a este fenômeno de insustentabilidade global. Assim, o Direito Penal, sem desfazer das funções de tutela cíveis e administrativas, tem sido um importante instrumento de tutela das questões ambientais. Para Freitas (2006) recorre-se ao Direito Penal "sempre que a repressão administrativa e civil se mostram insatisfatórias para combater as sucessivas agressões ao meio ambiente" .

Deixando de lado as Ordenações do Reino e a legislação do Império, temos em tempos republicanos no Decreto no 23.793 de 1934, denominado Código Florestal, o primeiro instrumento legal de proteção ao meio ambiente, tendo feito previsão de crimes e contravenções. Um pouco mais tarde, o Decreto-Lei no 2.848, de 7 de dezembro de 1940, nosso Código Penal, ainda em vigor, trouxe no Capítulo I, do Título VIII, dos crimes contra a incolumidade pública, e no Capítulo III, do mesmo título, dos crimes contra a saúde pública, que não deixam de ser crimes contra o meio ambiente sadio e equilibrado, como preceitua a Carta Magna.

Pode-se citar, um outro Código Florestal, desta feita através da Lei no 4.771 de 1965, e ainda a Lei de Proteção à Fauna (Lei № 5.197 de 1967), que estabeleceram condutas contravencionais ambientais anteriores à Constituição de 1988. Em 1975, uma das resoluções do Congresso Internacional de Direito Penal, realizado em Varsóvia, capital da Polônia, foi a de tratar as agressões ambientais como delitos contra a humanidade, e submetê-los à grave repressão. Este e outros eventos motivaram o constituinte quando citaram as esferas penal, administrativa e cível, quando da elaboração da Constituição Federal de 1988, que traz no seu Artigo 225으, §3을

Art. 225. Todos têm direito ao meio ambiente ecologicamente equilibrado, bem de uso comum do povo e essencial à sadia qualidade de vida, impondo-se ao poder público e à coletividade o dever de defendê-lo e preservá-lo para as presentes e futuras gerações.

$[\ldots]$

§ 3o As condutas e atividades consideradas lesivas ao meio ambiente sujeitarão os infratores, pessoas físicas ou jurídicas, a sanções penais e administrativas, independentemente da obrigação de reparar os danos causados.

Após a atual Constituição Federal, surgiram novos tipos penais com a Lei dos Agrotóxicos (Lei no 7.802 de 1989) e na Lei no 7.804 de 1989 que introduziu o crime de poluição sob qualquer forma. A Carta Magna fala em 'infratores' e não em 'criminosos', por isto, neste trabalho a denominação utilizada, que se julga mais adequada é de 'infrações ambientais criminais' e não de 'crimes ambientais'. Entendendo-se ainda que o uso de uma ou outra denominação não anula o conteúdo de obras relevantes consultadas.

Na seara 'administrativa ambiental' ou 'criminal ambiental', o operador do direito brasileiro não tem acesso a disciplinas densas e profundas interdisciplinares por conta de sua formação, que herda uma visão cartesiana e sem sistematização dos conteúdos com uma visão de todo. Mesmo operadores pós-formados não têm familiaridade com as nuanças da matéria e do processo, que se sugere autônomo, seja em Direito 
Penal Ambiental ou em Direito Administrativo Ambiental. Nestes termos, surge a necessidade de desenvolvimento e enquadramento científico do tema.

O objetivo geral desta pesquisa foi o de descrever a competência dos órgãos federais na persecução de infrações ambientais (penais ou administrativas) enquadradas na Lei no 9.605/98, demonstrando os fluxos de trabalho dos órgãos envolvidos, através de levantamento tipológico funcionalista, e fundamentação teórica pertinente, para dotar os operadores do Direito dos conhecimentos necessários para atuação nesta segmentação criminológica.

\section{METODOLOGIA}

A metodologia desta pesquisa foi iniciada com a definição da problemática, definida por Silva (2018), como a primeira etapa do ciclo de produção científica. Nesta etapa definem-se as relações de causas do problema e efeitos negativos, bem como o público-alvo atingido por estes. Esta pesquisa é tipológica ao ponto que lista e diferencia os órgãos federais competentes para a persecução em infrações ambientais, e é funcionalista ao ponto que descreve o fluxograma de trabalho dos órgãos até a oferta da denúncia.

Para coleta de dados referenciáveis (instrumento) desta pesquisa bibliográfica utilizou-se das palavras-chave: Direito Ambiental; Infrações Ambientais; Lei 9.605/98; Sanções Administrativas; Sanções Penais; e Competência de Órgãos Federais. Através de buscas em bases como Web of Science, DOAJ, Redalyc, EBSCO etc.

\section{DISCUSSÃO TEÓRICA}

\section{Fundamentos de Direito Penal Ambiental}

O princípio mais relevante do Direito Ambiental é o da Prevenção, que se caracteriza como repulsa aos crimes de perigo. Até a entrada em vigor da Lei n. 9.605 de 1998, a maioria dos crimes ambientais estavam incluídos na categoria de crimes de dano, deixando de lado a prevenção, e se consumando com a efetiva lesão ao bem jurídico (FREITAS, 2006). Para Lecey (1998),

mais importante do que punir é prevenir danos ao meio ambiente. Pela expressividade do dano coletivo em matéria ambiental, impõe-se reprimir para que não ocorra o dano. Por isso, a tipificação de muitas condutas de perigo até abstrato que, não-recomendável em matéria criminal, mostra-se necessária na proteção do meio ambiente.

As infrações ambientais podem ter repressão tutelada pelas vias administrativa (sanções mais eficientes e aplicadas com brevidade) e cível (possibilidade da reparação por completo) e, em última instância, a persecução penal, quando deve ser aplicado também o Princípio da Intervenção Mínima.

Na lição emanada por Bitencourt (1996), ao trazer à tona a Ultima Ratio, como princípio da intervenção mínima, que "orienta e limita o poder incriminador do Estado, preconizando que a criminalização de uma conduta só se legitima se constituir meio necessário para a proteção de determinado bem jurídico". Milaré (2018), também contribui com o pensamento, afirmando que “o princípio da intervenção mínima representa a inauguração de uma nova era no Direito Penal, onde este, mais do que nunca, é abordado como a Ultima Ratio em matéria de responsabilização jurídica". 
Enquanto o Princípio da Insignificância para Toledo (1982), "se revela por inteiro pela sua própria denominação, o Direito Penal, por sua natureza fragmentária, só vai até onde seja necessário para a proteção do bem jurídico. Não deve ocupar-se de bagatelas.". No entanto, Freitas (2006), deixa claro que "em matéria de meio ambiente, nem sempre é fácil distinguir o que é e o que não é significativo", e traz o exemplo da morte de animais em extinção, como uma Arara-Azul, que não pode ser tida como insignificante. O autor lembra ainda que as penas previstas na Lei de Crimes Ambientais (Lei no 9.605/98) são leves e admitem transação ou suspensão do processo (Lei no 9.099/95, arts. 76 e 89). O legislador quis respeitar o princípio da insignificância quando na Lei no 9.605/98, quando do artigo:

Art. 37. Não é crime o abate de animal, quando realizado:

I - em estado de necessidade, para saciar a fome do agente ou de sua família;

II - para proteger lavouras, pomares e rebanhos da ação predatória ou destruidora de animais, desde que legal e expressamente autorizado pela autoridade competente;

III - (VETADO)

IV - por ser nocivo o animal, desde que assim caracterizado pelo órgão competente.

A dificuldade de distinção faz surgir ações e precedentes, como o do relatório do Des. Fed. Tourinho

Neto, da 3aㅡ Turma do TRF-1a R., no RCCR n. 2004.34.00.021930-6/DF, de 17 de maio de 2005:

PROCESSUAL PENAL. CRIME AMBIENTAL. PRINCÍPIO DA INSIGNIFICÂNCIA. INAPLICABILIDADE. FLORESTA NACIONAL DE BRASÍLIA. ANÁLISE DA INEXISTÊNCIA DE NORMA LEGAL TRANSFORMANDO A ÁREA INVADIDA EM UNIDADE DE CONSERVAÇÃO SUBMETIDA AO JUÍZO A QUO. SUPRESSÃO DE INSTÂNCIA. 1. A ocupação ainda que de pequena área da Floresta Nacional de Brasília não pode ser considerada isoladamente, mas sim no contexto geral, pois a soma de pequenas áreas pode ter uma repercussão prejudicial ao meio ambiente. 2. Inviável a aplicação do princípio da insignificância em matéria ambiental, pois a biota, conjunto de seres animais e vegetais de uma região, pode se revelar extremamente diversificada, ainda que em nível local. 3. Limitando- se a decisão recorrida a rejeitar a denúncia com base no princípio da insignificância, sem tratar das normas legais que transformaram a área invadida em unidade de conservação, configura-se supressão de instância a análise do referido tema por ocasião do julgamento deste recurso em sentido estrito. 4. Recurso em sentido estrito provido.

A responsabilização administrativa e cível da pessoa jurídica, além da pessoa física, foi prevista na

Carta Magna de 1988 que traz no seu §3으 do art. 225, que "as condutas e atividades consideradas lesivas ao meio ambiente sujeitarão os infratores, pessoas físicas ou jurídicas, a sanções penais e administrativas, independentemente da obrigação de reparar os danos causados". Diferentemente das pessoas físicas, as possibilidades de sanções contra pessoas jurídicas serão: a multa; a pena restritiva de direitos; ou a prestação de serviços à coletividade.

Interessante o que traz o Acórdão proferido pela 8a Turma do TRF da 4ạ Região, no ACR. n. 2001.72.04.002225-0/SC, que teve como relator o Des. Federal Pinheiro de Castro, em 6 de agosto de 2003: CRIME CONTRA O MEIO AMBIENTE. EXTRAÇÃO DE PRODUTO MINERAL SEM AUTORIZAÇÃO. DEGRADAÇÃO DA FLORA NATIVA. ARTS. 48 E 55 DA LEI N. 9.605/98. CONDUTAS TÍPICAS. RESPONSABILIDADE PENAL DA PESSOA JURÍDICA. CABIMENTO. NULIDADES. INOCORRÊNCIA. PROVA. MATERIALIDADE E AUTORIA. SENTENÇA MANTIDA. 1. Segundo entendimento doutrinário e jurisprudencial predominante, a Constituição Federal (art. 225, $\S 3^{\circ}$ ), bem como a Lei n. 9.605/98 (art. $3^{\circ}$ ), inovaram o ordenamento penal pátrio, tornando possível a responsabilização criminal da pessoa jurídica. 2. Nos termos do art. 563 do Código de Processo Penal, nenhum ato será declarado nulo, se dele não resultar prejuízo à defesa (pas de nullité sans grief). 3. Na hipótese em tela, restou evidenciada a prática de extrair minerais sem autorização do DNPM, nem licença ambiental da Fatma, impedindo a regeneração da vegetação nativa do local. 4. Apelo desprovido.

Ainda sobre a penalização da pessoa jurídica, a Lei 9.605 de 1998 diz em seu art. 3o, que: 
Art. 2o Quem, de qualquer forma, concorre para a prática dos crimes previstos nesta Lei, incide nas penas a estes cominadas, na medida da sua culpabilidade, bem como o diretor, o administrador, o membro de conselho e de órgão técnico, o auditor, o gerente, o preposto ou mandatário de pessoa jurídica, que, sabendo da conduta criminosa de outrem, deixar de impedir a sua prática, quando podia agir para evitá-la.

Art. 3 As pessoas jurídicas serão responsabilizadas administrativa, civil e penalmente conforme o disposto nesta Lei, nos casos em que a infração seja cometida por decisão de seu representante legal ou contratual, ou de seu órgão colegiado, no interesse ou benefício da sua entidade.

Parágrafo único. A responsabilidade das pessoas jurídicas não exclui a das pessoas físicas, autoras, co-autoras ou partícipes do mesmo fato.

Art. 4 Poderá ser desconsiderada a pessoa jurídica sempre que sua personalidade for obstáculo ao ressarcimento de prejuízos causados à qualidade do meio ambiente.

Freitas (2006), lembra de interessante decisão da 6ạ Turma do Superior Tribunal de Justiça, no ROMS n. 16.696/PR, relatado pelo Min. Hamilton Carvalhido, em 09 de fevereiro de 2006, que trancou ação penal movida contra pessoa jurídica, sob o fundamento de que ela só pode ser responsabilizada junto com a pessoa física responsável:

RECURSO ORDINÁRIO EM MANDADO DE SEGURANÇA. DIREITO PROCESSUAL PENAL. CRIME AMBIENTAL. RESPONSABILIZAÇÃO DA PESSOA JURÍDICA. POSSIBILIDADE. TRANCAMENTO DA AÇÃO PENAL. INÉPCIA DA DENÚNCIA. OCORRÊNCIA. 1. Admitida a responsabilização penal da pessoa jurídica, por força de sua previsão constitucional, requisita a actio poenalis, para a sua possibilidade, a imputação simultânea da pessoa moral e da pessoa física que, mediata ou imediatamente, no exercício de sua qualidade ou atribuição conferida pelo estatuto social, pratique o fato-crime, atendendo-se, assim, ao princípio do nullum crimen sine actio humana. 2. Excluída a imputação aos dirigentes responsáveis pelas condutas incriminadas, o trancamento da ação penal, relativamente à pessoa jurídica, é de rigor. 3 . Recurso provido. Ordem de habeas corpus concedida de ofício.

Tal decisão é baseada no dito do art. 2o da lei penal ambiental, em que

Art. 2ㅇ Quem, de qualquer forma, concorre para a prática dos crimes previstos nesta Lei, incide nas penas a estes cominadas, na medida da sua culpabilidade, bem como o diretor, o administrador, o membro de conselho e de órgão técnico, o auditor, o gerente, 0 preposto ou mandatário de pessoa jurídica, que, sabendo da conduta criminosa de outrem, deixar de impedir a sua prática, quando podia agir para evitá-la.

\section{Elementos Normativos das Penas e dos Tipos previstos na Lei 9.605/98}

Tratando-se de Tipo Penal Ambiental, tem-se que a legislação traz normas penais em branco na sua maioria, que recorrem à títulos externos, como por exemplo as resoluções do CONAMA (Conselho Nacional do Meio Ambiente). A norma penal stricto sensu compõe-se de preceito e sanção, que Ihe permite aplicação sem a necessidade de consulta a outra norma, o que não é o caso para os tipos penais ambientais, na legislação brasileira.

Nem todas as infrações ou crimes ambientais são normas penais em branco, que podem ser complementadas por disposição prevista na mesma lei; por disposição prevista noutra lei; ou por disposição emanada por outro poder, que seja um ato administrativo. Tem-se por exemplo os artigos 32; 33; 35, I; 41; 66; 68; 69; e 69-A que não são normas penais em branco, tendo eficácia plena em si mesmos. Segundo Ramos (1986), para os crimes ambientais há necessidade de norma penal em branco, pois “há condutas que não se podem descrever sem acudir a esta técnica, dada sua complexidade (no meio ambiente, por exemplo, o conceito conexo de contaminação só pode ser determinado mediante uma remissão a outras normas)".

Nem sempre é possível aplicar o Princípio da Legalidade e o da Reserva Legal, previstos no artigo 1 o 
do Código Penal (CP) brasileiro, especialmente se tratando de infrações ou crimes ambientais, como mostra a lição de Fragoso (1958), de que existem tipos em que "não aparece expressa, por completo, a norma que o agente transgrede com seu comportamento, de tal maneira que não se contém no tipo a descrição completa do comportamento delituoso, que depende da transgressão de normas especiais que o tipo pressupõe".

Foi o desejo do Presidente da República, Fernando Henrique Cardoso, ao tempo da Lei no 9.605 de 1998, comunicar através de sua Mensagem de Veto 181 (BRASIL, 1998b), o veto parcial a tal legislação, quando percebeu a necessidade de norma penal em branco e de tipo penal aberto. $O$ projeto original da lei penal ambiental brasileira tinha em seu dispositivo o dizer "dispor sobre a criação e a aplicação de multas", após discussões, ainda em projeto, passou para "sistematizar as penalidades e unificar valores de multas a serem impostas aos infratores da fauna e da flora", tudo consta da Exposição de Motivos no 42 de 22 de abril de 1991, emanada pelo Secretário do Meio Ambiente. O veto ao art. 1ㅇ (BRASIL, 1998b), conclui que:

Não obstante a intenção do legislador, o projeto não alcançou a abrangência que se lhe pretendeu imprimir, pois não incluiu todas as condutas que são hoje punidas por nocivas ao meio ambiente. Como exemplo, cite-se: o crime de difusão de doença ou praga, contigo no art. 259 do Código Penal; a proibição da pesca de cetáceos (baleias, golfinhos, etc...) nas águas jurisdicionais brasileiras, nos termos do art. 2 ㅇ da Lei $n$. 7.643, de 18 de dezembro de 1987, ou a contravenção prevista na alínea "m" do art. 26 da Lei n. 4.771/65 (soltar animais ou não tomar precauções para que o animal de sua propriedade não penetre em florestas sujeitas a regime especial.

Se mantido o art. 1ํ, condutas como estas não mais poderiam ser coibidas. Com o veto, permanecem em vigor as atuais proibições, mesmo que não inclusas nesta lei.

Em termos de aplicação da pena, a própria disposição legal da Lei no 9.605 de 1998, faz diferenciação entre sanções penais e administrativas. Segundo Guimarães (2013), pena é a "sanção legal, punição ou cominação prevista em lei, que o Estado impõe àquele que infringe norma de direito". Para gradação da penalidade, a autoridade deverá observar o que diz os incisos do art. 6ㅇ:

Art. 6o Para imposição e gradação da penalidade, a autoridade competente observará:

I - a gravidade do fato, tendo em vista os motivos da infração e suas consequências para a saúde pública e para o meio ambiente;

II - os antecedentes do infrator quanto ao cumprimento da legislação de interesse ambiental;

III - a situação econômica do infrator, no caso de multa.

Conforme o art. 70 as penas restritivas de direitos são autônomas, e substituem as penas privativas de liberdade, quando:

Art. 7으 As penas restritivas de direitos são autônomas e substituem as privativas de liberdade quando:

I - tratar-se de crime culposo ou for aplicada a pena privativa de liberdade inferior a 4 (quatro) anos;

II - a culpabilidade, os antecedentes, a conduta social e a personalidade do condenado, bem como os motivos e as circunstâncias do crime indicarem que a substituição seja suficiente para efeitos de reprovação e prevenção do crime.

Parágrafo único. As penas restritivas de direitos a que se refere este artigo terão a mesma duração da pena privativa de liberdade substituída.

Conforme o art. 8으, da Lei de Infrações Ambientais, as penas restritivas de direitos aplicáveis são: Iprestação de serviços à comunidade; II - interdição temporária de direitos; III - suspensão parcial ou total de atividades; IV - prestação pecuniária; e V - recolhimento domiciliar. O legislador fez questão de detalhar as penas listadas no art. 8 ํ através dos artigos 9 o ao 24, aplicáveis às pessoas físicas e/ou jurídicas. 
Conforme o art. 72, da Lei de Infrações Ambientais, regulamentada pelo Decreto no 6.514/98, a infrações administrativa, que conforme o art. 70, é "toda ação ou omissão que viole as regras jurídicas de uso, gozo, promoção, proteção, e recuperação do meio ambiente", são puníveis com as seguintes sanções: I - advertência; II - multa simples; III - multa diária; IV - apreensão dos animais, produtos e subprodutos da fauna e flora, instrumentos, petrechos, equipamentos ou veículos de qualquer natureza utilizados na infração; V - destruição ou inutilização do produto; VI - suspensão de venda e fabricação do produto; VII embargo de obra ou atividade; VIII - demolição de obra; IX - suspensão parcial ou total de atividades; X (VETADO); XI - restritiva de direitos".

Sobre apreensão do produto e do instrumento de infração administrativa ou de crime, o legislador autoriza a apreensão e lavratura de autos no art. 25 e seus parágrafos. Os animais apreendidos devem ser liberados em seu habitat natural quando possível, e, em contrário, deverão ser encaminhados a locais aptos à guarda e cuidados. Materiais perecíveis devem ser encaminhados a instituições beneficentes. Materiais não-perecíveis também poderão ser doados a instituições beneficentes, ou serão destruídos em caso de inutilidade.

Quadro 01: Consolidação de Tipos, Preceitos, Sanções e Observações da Lei no 9.605/98.

\begin{tabular}{|c|c|c|c|}
\hline Tipo & Preceito & Sanção & Observações \\
\hline $\begin{array}{l}\text { Art. } \\
29\end{array}$ & $\begin{array}{l}\text { Matar, perseguir, caçar, apanhar, utilizar espécimes da fauna } \\
\text { silvestre, nativos ou em rota migratória, sem a devida permissão, } \\
\text { licença ou autorização da autoridade competente, ou em } \\
\text { desacordo com a obtida. }\end{array}$ & $\begin{array}{l}\text { Detenção, de } 6 \text { (seis) meses a } 1 \text { (um) } \\
\text { ano, e multa. }\end{array}$ & $\S 1$ ao $\S 60$ \\
\hline $\begin{array}{l}\text { Art. } \\
30\end{array}$ & $\begin{array}{l}\text { Exportar para o exterior peles e couros de anfíbios e répteis em } \\
\text { bruto, sem a autorização da autoridade ambiental competente. }\end{array}$ & Reclusão, de um a três anos, e multa. & \\
\hline $\begin{array}{l}\text { Art. } \\
31\end{array}$ & $\begin{array}{l}\text { Introduzir espécime animal no País, sem parecer técnico oficial } \\
\text { favorável e licença expedida por autoridade competente. }\end{array}$ & $\begin{array}{l}\text { Detenção, de três meses a um ano, e } \\
\text { multa. }\end{array}$ & \\
\hline $\begin{array}{l}\text { Art. } \\
32\end{array}$ & $\begin{array}{l}\text { Praticar ato de abuso, maus-tratos, ferir ou mutilar animais } \\
\text { silvestres, domésticos ou domesticados, nativos ou exóticos. }\end{array}$ & $\begin{array}{l}\text { Detenção, de três meses a um ano, e } \\
\text { multa. }\end{array}$ & $\S 1$ e e $\S 20$ \\
\hline $\begin{array}{l}\text { Art. } \\
33\end{array}$ & $\begin{array}{l}\text { Provocar, pela emissão de efluentes ou carreamento de materiais, } \\
\text { o perecimento de espécimes da fauna aquática existentes em rios, } \\
\text { lagos, açudes, lagoas, baías ou águas jurisdicionais brasileiras. }\end{array}$ & $\begin{array}{l}\text { Detenção, de um a três anos, ou multa, } \\
\text { ou ambas cumulativamente. }\end{array}$ & § Único \\
\hline $\begin{array}{l}\text { Art. } \\
34\end{array}$ & $\begin{array}{l}\text { Pescar em período no qual a pesca seja proibida ou em lugares } \\
\text { interditados por órgão competente. }\end{array}$ & $\begin{array}{l}\text { Detenção de um ano a três anos ou } \\
\text { multa, ou ambas as penas } \\
\text { cumulativamente. }\end{array}$ & § Único \\
\hline $\begin{array}{l}\text { Art. } \\
35 .\end{array}$ & $\begin{array}{l}\text { Pescar mediante a utilização de: I - explosivos ou substâncias que, } \\
\text { em contato com a água, produzam efeito semelhante; II - } \\
\text { substâncias tóxicas, ou outro meio proibido pela autoridade } \\
\text { competente. }\end{array}$ & Reclusão de um ano a cinco anos. & \\
\hline $\begin{array}{l}\text { Art. } \\
38\end{array}$ & $\begin{array}{l}\text { Destruir ou danificar floresta considerada de preservação } \\
\text { permanente, mesmo que em formação, ou utilizá-la com } \\
\text { infringência das normas de proteção. }\end{array}$ & $\begin{array}{l}\text { Detenção, de um a três anos, ou multa, } \\
\text { ou ambas as penas cumulativamente. }\end{array}$ & § Único \\
\hline $\begin{array}{l}\text { Art. } \\
38-A\end{array}$ & $\begin{array}{l}\text { Destruir ou danificar vegetação primária ou secundária, em estágio } \\
\text { avançado ou médio de regeneração, do Bioma Mata Atlântica, ou } \\
\text { utilizá-la com infringência das normas de proteção. }\end{array}$ & $\begin{array}{l}\text { Detenção, de } 1 \text { (um) a } 3 \text { (três) anos, ou } \\
\text { multa, ou ambas as penas } \\
\text { cumulativamente. }\end{array}$ & $\S$ Único \\
\hline $\begin{array}{l}\text { Art. } \\
39\end{array}$ & $\begin{array}{l}\text { Cortar árvores em floresta considerada de preservação } \\
\text { permanente, sem permissão da autoridade competente. }\end{array}$ & $\begin{array}{l}\text { Detenção, de um a três anos, ou multa, } \\
\text { ou ambas as penas cumulativamente. }\end{array}$ & \\
\hline $\begin{array}{l}\text { Art. } \\
40\end{array}$ & $\begin{array}{l}\text { Causar dano direto ou indireto às Unidades de Conservação e às } \\
\text { áreas de que trata o art. } 27 \text { do Decreto no } 99.274 \text {, de } 6 \text { de junho de } \\
1990, \text { independentemente de sua localização. }\end{array}$ & Reclusão, de um a cinco anos. & 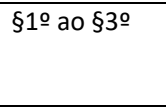 \\
\hline $\begin{array}{l}\text { Art. } \\
41\end{array}$ & Provocar incêndio em mata ou floresta. & $\begin{array}{l}\text { Reclusão, de dois a quatro anos, e } \\
\text { multa. }\end{array}$ & $\S$ Único \\
\hline $\begin{array}{l}\text { Art. } \\
42\end{array}$ & $\begin{array}{l}\text { Fabricar, vender, transportar ou soltar balões que possam } \\
\text { provocar incêndios nas florestas e demais formas de vegetação, } \\
\text { em áreas urbanas ou qualquer tipo de assentamento humano. }\end{array}$ & $\begin{array}{l}\text { Detenção de um a três anos ou multa, } \\
\text { ou ambas as penas cumulativamente. }\end{array}$ & \\
\hline $\begin{array}{l}\text { Art. } \\
44\end{array}$ & $\begin{array}{l}\text { Extrair de florestas de domínio público ou consideradas de } \\
\text { preservação permanente, sem prévia autorização, pedra, areia, cal } \\
\text { ou qualquer espécie de minerais. }\end{array}$ & $\begin{array}{l}\text { Detenção, de seis meses a um ano, e } \\
\text { multa. }\end{array}$ & \\
\hline $\begin{array}{l}\text { Art. } \\
45\end{array}$ & $\begin{array}{l}\text { Cortar ou transformar em carvão madeira de lei, assim classificada } \\
\text { por ato do Poder Público, para fins industriais, energéticos ou para } \\
\text { qualquer outra exploração, econômica ou não, em desacordo com } \\
\text { as determinações legais. }\end{array}$ & Reclusão, de um a dois anos, e multa. & \\
\hline
\end{tabular}




\begin{tabular}{|c|c|c|c|}
\hline $\begin{array}{l}\text { Art. } \\
46\end{array}$ & $\begin{array}{l}\text { Receber ou adquirir, para fins comerciais ou industriais, madeira, } \\
\text { lenha, carvão e outros produtos de origem vegetal, sem exigir a } \\
\text { exibição de licença do vendedor, outorgada pela autoridade } \\
\text { competente, e sem munir-se da via que deverá acompanhar o } \\
\text { produto até final beneficiamento. }\end{array}$ & $\begin{array}{l}\text { Detenção, de seis meses a um ano, e } \\
\text { multa. }\end{array}$ & $\S$ Único \\
\hline $\begin{array}{l}\text { Art. } \\
48\end{array}$ & $\begin{array}{l}\text { Impedir ou dificultar a regeneração natural de florestas e demais } \\
\text { formas de vegetação. }\end{array}$ & $\begin{array}{l}\text { Detenção, de seis meses a um ano, e } \\
\text { multa. }\end{array}$ & \\
\hline $\begin{array}{l}\text { Art. } \\
49\end{array}$ & $\begin{array}{l}\text { Destruir, danificar, lesar ou maltratar, por qualquer modo ou meio, } \\
\text { plantas de ornamentação de logradouros públicos ou em } \\
\text { propriedade privada alheia. }\end{array}$ & $\begin{array}{l}\text { Detenção, de três meses a um ano, ou } \\
\text { multa, ou ambas as penas } \\
\text { cumulativamente. }\end{array}$ & § Único \\
\hline $\begin{array}{l}\text { Art. } \\
50\end{array}$ & $\begin{array}{l}\text { Destruir ou danificar florestas nativas ou plantadas ou vegetação } \\
\text { fixadora de dunas, protetora de mangues, objeto de especial } \\
\text { preservação }\end{array}$ & $\begin{array}{l}\text { Detenção, de três meses a um ano, e } \\
\text { multa. }\end{array}$ & \\
\hline $\begin{array}{l}\text { Art. } \\
50-A\end{array}$ & $\begin{array}{l}\text { Desmatar, explorar economicamente ou degradar floresta, } \\
\text { plantada ou nativa, em terras de domínio público ou devolutas, } \\
\text { sem autorização do órgão competente. }\end{array}$ & $\begin{array}{l}\text { Reclusão de } 2 \text { (dois) a } 4 \text { (quatro) anos e } \\
\text { multa. }\end{array}$ & $\S 10$ e $\S 2^{\circ}$ \\
\hline $\begin{array}{l}\text { Art. } \\
51\end{array}$ & $\begin{array}{l}\text { Comercializar motosserra ou utilizá-la em florestas e nas demais } \\
\text { formas de vegetação, sem licença ou registro da autoridade } \\
\text { competente. }\end{array}$ & $\begin{array}{l}\text { Detenção, de três meses a um ano, e } \\
\text { multa. }\end{array}$ & \\
\hline $\begin{array}{l}\text { Art. } \\
52\end{array}$ & $\begin{array}{l}\text { Penetrar em Unidades de Conservação conduzindo substâncias ou } \\
\text { instrumentos próprios para caça ou para exploração de produtos } \\
\text { ou subprodutos florestais, sem licença da autoridade competente. }\end{array}$ & $\begin{array}{l}\text { Detenção, de seis meses a um ano, e } \\
\text { multa. }\end{array}$ & \\
\hline $\begin{array}{l}\text { Art. } \\
54\end{array}$ & $\begin{array}{l}\text { Causar poluição de qualquer natureza em níveis tais que resultem } \\
\text { ou possam resultar em danos à saúde humana, ou que provoquem } \\
\text { a mortandade de animais ou a destruição significativa da flora. }\end{array}$ & Reclusão, de um a quatro anos, e multa. & $\S 1$ ao $\S 3 ㅇ$ \\
\hline $\begin{array}{l}\text { Art. } \\
55\end{array}$ & $\begin{array}{l}\text { Executar pesquisa, lavra ou extração de recursos minerais sem a } \\
\text { competente autorização, permissão, concessão ou licença, ou em } \\
\text { desacordo com a obtida. }\end{array}$ & $\begin{array}{l}\text { Detenção, de seis meses a um ano, e } \\
\text { multa. }\end{array}$ & $\S$ Único \\
\hline $\begin{array}{l}\text { Art. } \\
56\end{array}$ & $\begin{array}{l}\text { Produzir, processar, embalar, importar, exportar, comercializar, } \\
\text { fornecer, transportar, armazenar, guardar, ter em depósito ou usar } \\
\text { produto ou substância tóxica, perigosa ou nociva à saúde humana } \\
\text { ou ao meio ambiente, em desacordo com as exigências } \\
\text { estabelecidas em leis ou nos seus regulamentos. }\end{array}$ & Reclusão, de um a quatro anos, e multa. & $\S 10$ ao 330 \\
\hline $\begin{array}{l}\text { Art. } \\
60\end{array}$ & $\begin{array}{l}\text { Construir, reformar, ampliar, instalar ou fazer funcionar, em } \\
\text { qualquer parte do território nacional, estabelecimentos, obras ou } \\
\text { serviços potencialmente poluidores, sem licença ou autorização } \\
\text { dos órgãos ambientais competentes, ou contrariando as normas } \\
\text { legais e regulamentares pertinentes. }\end{array}$ & $\begin{array}{l}\text { Detenção, de um a seis meses, ou } \\
\text { multa, ou ambas as penas } \\
\text { cumulativamente. }\end{array}$ & \\
\hline $\begin{array}{l}\text { Art. } \\
61\end{array}$ & $\begin{array}{l}\text { Disseminar doença ou praga ou espécies que possam causar dano } \\
\text { à agricultura, à pecuária, à fauna, à flora ou aos ecossistemas. }\end{array}$ & Reclusão, de um a quatro anos, e multa. & \\
\hline $\begin{array}{l}\text { Art. } \\
62\end{array}$ & $\begin{array}{l}\text { Destruir, inutilizar ou deteriorar: I - bem especialmente protegido } \\
\text { por lei, ato administrativo ou decisão judicial; II - arquivo, registro, } \\
\text { museu, biblioteca, pinacoteca, instalação científica ou similar } \\
\text { protegido por lei, ato administrativo ou decisão judicial. }\end{array}$ & Reclusão, de um a três anos, e multa. & § Único \\
\hline $\begin{array}{l}\text { Art. } \\
63\end{array}$ & $\begin{array}{l}\text { Alterar o aspecto ou estrutura de edificação ou local } \\
\text { especialmente protegido por lei, ato administrativo ou decisão } \\
\text { judicial, em razão de seu valor paisagístico, ecológico, turístico, } \\
\text { artístico, histórico, cultural, religioso, arqueológico, etnográfico ou } \\
\text { monumental, sem autorização da autoridade competente ou em } \\
\text { desacordo com a concedida. }\end{array}$ & Reclusão, de um a três anos, e multa. & \\
\hline $\begin{array}{l}\text { Art. } \\
64\end{array}$ & $\begin{array}{l}\text { Promover construção em solo não edificável, ou no seu entorno, } \\
\text { assim considerado em razão de seu valor paisagístico, ecológico, } \\
\text { artístico, turístico, histórico, cultural, religioso, arqueológico, } \\
\text { etnográfico ou monumental, sem autorização da autoridade } \\
\text { competente ou em desacordo com a concedida. }\end{array}$ & $\begin{array}{l}\text { Detenção, de seis meses a um ano, e } \\
\text { multa. }\end{array}$ & \\
\hline $\begin{array}{l}\text { Art. } \\
65\end{array}$ & $\begin{array}{l}\text { Pichar ou por outro meio conspurcar edificação ou monumento } \\
\text { urbano. }\end{array}$ & $\begin{array}{l}\text { Detenção, de } 3 \text { (três) meses a } 1 \text { (um) } \\
\text { ano, e multa. }\end{array}$ & \\
\hline $\begin{array}{l}\text { Art. } \\
66\end{array}$ & $\begin{array}{l}\text { Fazer o funcionário público afirmação falsa ou enganosa, omitir a } \\
\text { verdade, sonegar informações ou dados técnico-científicos em } \\
\text { procedimentos de autorização ou de licenciamento ambiental. }\end{array}$ & Reclusão, de um a três anos, e multa. & \\
\hline $\begin{array}{l}\text { Art. } \\
67\end{array}$ & $\begin{array}{l}\text { Conceder o funcionário público licença, autorização ou permissão } \\
\text { em desacordo com as normas ambientais, para as atividades, } \\
\text { obras ou serviços cuja realização depende de ato autorizativo do } \\
\text { Poder Público. }\end{array}$ & Detenção, de um a três anos, e multa. & § Único \\
\hline $\begin{array}{l}\text { Art. } \\
68\end{array}$ & $\begin{array}{l}\text { Deixar, aquele que tiver o dever legal ou contratual de fazê-lo, de } \\
\text { cumprir obrigação de relevante interesse ambiental: }\end{array}$ & Detenção, de um a três anos, e multa. & § Único \\
\hline $\begin{array}{l}\text { Art. } \\
69\end{array}$ & $\begin{array}{l}\text { Obstar ou dificultar a ação fiscalizadora do Poder Público no trato } \\
\text { de questões ambientais. }\end{array}$ & Detenção, de um a três anos, e multa. & \\
\hline $\begin{array}{l}\text { Art. } \\
69-A\end{array}$ & $\begin{array}{l}\text { Elaborar ou apresentar, no licenciamento, concessão florestal ou } \\
\text { qualquer outro procedimento administrativo, estudo, laudo ou } \\
\text { relatório ambiental total ou parcialmente falso ou enganoso, } \\
\text { inclusive por omissão. }\end{array}$ & $\begin{array}{l}\text { Reclusão, de } 3 \text { (três) a } 6 \text { (seis) anos, e } \\
\text { multa. }\end{array}$ & $\S 10$ e $\S 2 \circ$ \\
\hline $\begin{array}{l}\text { Art. } \\
70\end{array}$ & $\begin{array}{l}\text { Considera-se infração administrativa ambiental toda ação ou } \\
\text { omissão que viole as regras jurídicas de uso, gozo, promoção, } \\
\text { proteção e recuperação do meio ambiente. }\end{array}$ & $\begin{array}{l}\text { I - advertência; } \\
\text { II - multa simples; } \\
\text { III - multa diária; }\end{array}$ & $\begin{array}{l}\text { Art. } 70 \text { ao } 76, \\
\text { regulamentados pelo } \\
\text { Decreto } n=6.514 / 98 \text {. }\end{array}$ \\
\hline
\end{tabular}




\begin{tabular}{|l|l|l|}
\hline & IV - apreensão dos animais, produtos e \\
subprodutos da fauna e flora, \\
instrumentos, petrechos, equipamentos \\
ou veículos de qualquer natureza \\
utilizados na infração; \\
V - destruição ou inutilização do \\
produto; \\
VI - suspensão de venda e fabricação do \\
produto; \\
VII - embargo de obra ou atividade; \\
VIII - demolição de obra; \\
IX - suspensão parcial ou total de \\
atividades; \\
X- (VETADO) \\
XI - restritiva de direitos. \\
\hline
\end{tabular}

Observação relevante: a reclusão é mais severa e poderá ser cumprida em regime fechado, semiaberto, ou aberto. A detenção é mais leve e não admite regime fechado. Fonte: Lei 9.605/1998 (BRASIL, 1998a).

\section{Competência de Autuação e Persecução de Infrações ou Crimes Ambientais}

A responsabilização, seja administrativa, penal ou cível das infrações ambientais dependerá dos níveis de corrupção e desenvolvimento de cada nação. Em países mais desenvolvidos as questões ambientais serão tratadas pela via administrativa e cível, enquanto em países subdesenvolvidos e pobres a persecução necessita ser mais rigorosa, e portanto penal (FREITAS, 2006). Nos Estados Unidos da América (EUA) a persecução por infrações ambientais é realizada pela EPA (Environmental Police Agency), onde pouquíssimos casos são levados ao judiciário; o Uruguai baseia-se na Lei no 17.283 , de 2000, e resolve a maioria de suas questões ambientais na esfera administrativa; na Argentina a legislação civil assume papel principal na proteção do meio ambiente (FREITAS, 2006).

A doutrina majoritária na legislação brasileira traz duas significações diversas ao significado da atividade de polícia: a de polícia administrativa (Direito Administrativo), e a de política judiciária ou investigativa (Direito Penal). Para Sidou (2016), polícia administrativa é mais que um órgão específico, e sim, o "conjunto de serviços organizados pela administração para assegurar a ordem pública e garantir a integridade física e moral das pessoas, mediante limitações impostas à atividade do agente que as possa molestar". Guimarães (2013), por sua vez, traz que, a polícia judiciária é "aquela à qual incube a investigação e apuração de fraudes e infrações à norma penal, prisão de seus autores, reunião de provas contra eles, em inquérito policial regular, que é entregue à Justiça como base do procedimento criminal". Tratando-se de infrações ambientais tem-se no Brasil uma complexa percepção de competências, como demonstrado no Quadro 02.

Quadro 02: Funções, esferas, órgãos policiais competentes, e previsão legal.

\begin{tabular}{|c|c|c|c|}
\hline Função & Esfera & Ente da Administração & $\begin{array}{l}\text { Previsão Legal } \\
\end{array}$ \\
\hline Administrativa & Federal, estadual, ou municipal & $\begin{array}{l}\text { IBAMA - Instituto Brasileiro do Meio } \\
\text { Ambiente e dos Recursos Naturais } \\
\text { Renováveis }\end{array}$ & $\begin{array}{l}\text { - Lei no } 6.938 \text { de 1981, Art. 6o, IV; } \\
\text { - Lei no } 9.605 \text { de 1998, Art. 70, } \\
\text { §1o; } \\
\text { - Instrução Normativa no } 10 \text { de } \\
2012 \text { do IBAMA. }\end{array}$ \\
\hline Administrativa & $\begin{array}{l}\text { Federal (específico para } \\
\text { Unidades de Conservação } \\
\text { tuteladas pela União) }\end{array}$ & $\begin{array}{l}\text { ICMBIO - Instituto Chico Mendes de } \\
\text { Conservação da Biodiversidade }\end{array}$ & $\begin{array}{l}\text { - Lei no } 6.938 \text { de } 1981 \text {, Art. } 6 \text { o, IV } \\
\text { com redação dada pela Lei } 11.516 \\
\text { de } 2007 \text {, Art. } 1 \text { ㅇ, IV. }\end{array}$ \\
\hline Administrativa & Federal (rodovias federais) & $\begin{array}{l}\text { PRF - Polícia Rodoviária Federal; PFF } \\
\text { - Polícia Ferroviária Federal }\end{array}$ & $\begin{array}{l}\text { - CF, Art. 144, II e III; } \\
\text { - Lei no } 9.503 \text { de } 1997 \text { (СTB), Art. } \\
\text { 7o, V. }\end{array}$ \\
\hline Administrativa & Federal & Capitania dos Portos (Marinha do & Lei no 9.605 de 1998, Art. 70, §1으 \\
\hline
\end{tabular}




\begin{tabular}{|l|l|l|l|}
\hline & & Brasil) & \\
\hline Administrativa & Estadual ou municipal & $\begin{array}{l}\text { Secretária ou Agência Estadual do } \\
\text { Meio Ambiente }\end{array}$ & - Lei no 6.938 de 1981, Art. 6o, V. \\
\hline Administrativa & Estadual ou municipal & $\begin{array}{l}\text { PM - Polícia Militar Estadual e do } \\
\text { Distrito Federal; CBM - Corpo de } \\
\text { Bombeiros Militares }\end{array}$ & $\begin{array}{l}\text { - CF, Art. 144, V; } \\
\text { - Lei no 9.503 de 1997 (CTB), Art. } \\
\text { 7oo, VI. }\end{array}$ \\
\hline Administrativa & Municipal & $\begin{array}{l}\text { Secretária ou Agência Municipal do } \\
\text { Meio Ambiente }\end{array}$ & - Lei no 6.938 de 1981, Art. 60, VI. \\
\hline Administrativa & Municipal & Guarda Municipal & - CF, Art. 144, §8ㅇ \\
\hline Judiciária & $\begin{array}{l}\text { Internacional, federal ou } \\
\text { estadual }\end{array}$ & PF - Polícia Federal & - CF, Art. 144, I; \\
Judiciária & Estadual & PC - Polícia Civil & 10.446 de 2002 \\
\hline
\end{tabular}

Lembrando que o art. 23 da CF prevê a competência comum da União, dos Estados, do Distrito Federal e dos Municípios: em seu inciso VI, para "proteger o meio ambiente e combater a poluição em qualquer de suas formas"; no inciso VII, para "preservar as florestas, a fauna e a flora". Já o inciso V, do art. 24 da CF prevê a competência concorrente de legislar sobre: "florestas, caça, pesca, fauna, conservação da natureza, defesa do solo e dos recursos naturais, proteção do meio ambiente e controle da poluição". 0 art. 22 da Constituição Federal de 1988, em seu inciso 22 garante à União, a competência privativa de legislar sobre a competência da polícia federal e das polícias rodoviária e ferroviária federais.

Do art. 144 da CF extrai-se que o Estado irá exercer seu poder de segurança pública através de determinados órgãos, o que não excluí as possibilidades de atuação de outros órgãos, e ainda dos próprios cidadãos, quando fala em "direito e responsabilidade de todos":

Art. 144. A segurança pública, dever do Estado, direito e responsabilidade de todos, é exercida para a preservação da ordem pública e da incolumidade das pessoas e do patrimônio, através dos seguintes órgãos:

I - polícia federal;

II - polícia rodoviária federal;

III - polícia ferroviária federal;

IV - polícias civis;

V - polícias militares e corpos de bombeiros militares. "a segurança pública, dever do Estado, direito e responsabilidade de todos, é exercida para a preservação da ordem pública e da incolumidade das pessoas e do patrimônio, através dos seguintes órgãos:"

Sobre a legitimidade popular para fiscalizar o meio ambiente vale lembrar que, segundo o art. 50 da $\mathrm{CF}$, ao tratar dos Direitos Fundamentais, em seu inciso LXXIII, preceitua que "qualquer cidadão é parte legítima para propor ação popular que vise a anular ato lesivo ao patrimônio público ou de entidade de que o Estado participe, à moralidade administrativa, ao meio ambiente e ao patrimônio histórico e cultural, ficando o autor, salvo comprovada má-fé, isento de custas judiciais e do ônus da sucumbência".

Todos os órgãos de função administrativa citados anteriormente são considerados autoridades ambientais, com exceção do cidadão, que apenas tem o direito e o dever de atuar na proteção do meio ambiente. Conforme art. 70, §3ㅇ da Lei de Infrações Ambientais, é competente para instaurar procedimento administrativo próprio a autoridade que conhecer da infração, sendo obrigada a promover apuração imediata, sob pena de corresponsabilidade. O direito de ampla defesa e contraditório é assegurado.

Conforte art. 73 da Lei no 9.605/98, todos os recursos financeiros auferidos através de multas por infração ambiental deverão ser revertidos ao Fundo Nacional do Meio Ambiente, criado pela Lei no 7.797/89, ao Fundo Naval, criado pelo Decreto no 20.923/32, aos fundos estaduais, municipais e correlatos criados para 
fins de proteção da natureza e dos recursos naturais renováveis, conforme dispuser o órgão competente arrecadador.

\section{IBAMA e ICMBIO}

O Instituto Brasileiro do Meio Ambiente e dos Recursos Naturais Renováveis (IBAMA) tem competência atribuída como órgão do Sistema Nacional do Meio Ambiente (SISNAMA), conforme previsto no art. 70, §1으, da Lei no 9.605 de 1998. A Instrução Normativa oo 10 de 2012 do IBAMA, regula os procedimentos para apuração de infrações administrativas por condutas e atividades lesivas ao meio ambiente, a imposição das sanções, a defesa ou a impugnação, o sistema recursal e a cobrança de multa no âmbito do órgão.

O SISNAMA foi instituído pela Lei no 6.938 de 31 de agosto de 1981, regulamentada pelo Decreto no 99.274 de 06 de junho de 1990, sendo constituído pelos órgãos e entidades da União, dos Estados, do Distrito Federal, dos Municípios e pelas Fundações instituídas pelo Poder Público, responsáveis pela proteção e melhoria da qualidade ambiental, e é composto nesta hierarquia pelo: Conselho de Governo; Conselho Nacional do Meio Ambiente; Ministério do Meio Ambiente; Instituto Brasileiro do Meio Ambiente e dos Recursos Naturais Renováveis; Instituto Chico Mendes de Conservação da Biodiversidade; órgãos ou entidades estaduais responsáveis pela execução de programas, projetos e pelo controle e fiscalização de atividades capazes de provocar a degradação ambiental; órgãos ou entidades municipais, responsáveis pelo controle e fiscalização dessas atividades, nas suas respectivas jurisdições.

O Instituto Chico Mendes de Conservação da Biodiversidade (ICMBIO) foi criado com a segmentação do IBAMA, através da Lei no 6.938 de 1981, Art. 6o, IV com redação dada pela Lei 11.516 de 2007, Art. 1으, IV. O órgão é competente para autuar infrações ambientais cometidas no âmbito das unidades de conservação sob tutela da União.

\section{Polícia Rodoviária Federal}

A Polícia Rodoviária Federal (PRF) tem competência atribuída pela Constituição Federal no §2ํ do art. 144, enquanto a Polícia Ferroviária Federal (PFF) tem competência atribuída pelo §3ㅇ do art. 144 da Carta Magna. Para Dallari (1997), a competência constitucional da Polícia Rodoviária Federal (PRF), limita-se ao "patrulhamento ostensivo das rodovias federais", e, portanto, competente para atuar como polícia administrativa em ilícitos ambientais, especialmente ligados a cargas perigosas e a animais abandonados ou em situação de maus tratos. Pelo escrito da Lei no 9.503 de 1997 (Código de Trânsito Brasileiro), em seu art. 7ํㅡ, inciso V, os departamentos rodoviários das Polícias Militares estaduais e do Distrito Federal, seguem o mesmo caminho nas infrações ambientais. Extrai-se do Código de Trânsito Brasileiro, que:

Art. 6․ São objetivos básicos do Sistema Nacional de Trânsito:

I - estabelecer diretrizes da Política Nacional de Trânsito, com vistas à segurança, à fluidez, ao conforto, à defesa ambiental e à educação para o trânsito, e fiscalizar seu cumprimento;

Art. 20. Compete à Polícia Rodoviária Federal, no âmbito das rodovias e estradas federais: $[\ldots]$ 
III - aplicar e arrecadar as multas impostas por infrações de trânsito, as medidas administrativas decorrentes e os valores provenientes de estada e remoção de veículos, objetos, animais e escolta de veículos de cargas superdimensionadas ou perigosas;

Art. 24. Compete aos órgãos e entidades executivos de trânsito dos Municípios, no âmbito de sua circunscrição:

$[\ldots]$

$X X$ - fiscalizar o nível de emissão de poluentes e ruído produzidos pelos veículos automotores ou pela sua carga, de acordo com o estabelecido no art. 66, além de dar apoio às ações específicas de órgão ambiental local, quando solicitado;

Art. 26. Os usuários das vias terrestres devem:

I - abster-se de todo ato que possa constituir perigo ou obstáculo para o trânsito de veículos, de pessoas ou de animais, ou ainda causar danos a propriedades públicas ou privadas;

Art. 235. Conduzir pessoas, animais ou carga nas partes externas do veículo, salvo nos casos devidamente autorizados:

Infração - grave;

Penalidade - multa;

Medida administrativa - retenção do veículo para transbordo.

Art. 269. A autoridade de trânsito ou seus agentes, na esfera das competências estabelecidas neste Código e dentro de sua circunscrição, deverá adotar as seguintes medidas administrativas:

$[\ldots]$

$X$ - recolhimento de animais que se encontrem soltos nas vias e na faixa de domínio das vias de circulação, restituindo-os aos seus proprietários, após o pagamento de multas e encargos devidos.

[...]

$\S 4$ ㅇ Aplica-se aos animais recolhidos na forma do inciso X o disposto nos arts. 271 e 328, no que couber.

Compete exclusivamente à Polícia Rodoviária Federal (PRF), nos termos das resoluções da Agência Nacional de Transportes Terrestres (ANTT) a fiscalização de produtos perigosos em transporte nas rodovias federais. Produtos perigosos podem ser classificados como explosivos, gases, líquidos inflamáveis, sólidos inflamáveis, oxidantes, peróxidos orgânicos, tóxicos, infectantes, radioativos, corrosivos e substâncias que afetam o meio ambiente.

Nos termos do Regulamento para Transporte Rodoviário de Produtos Perigosos (Resolução ANTT no. 3665/11) atualizado pela Resolução ANTT no 5.848/19 (em vigor a partir de dezembro de 2019), essas normas penais em branco complementadas pelas especificações da Resolução ANTT no 5.232/16, e instruída pela Instrução Normativa no 64 (PRF, 2015), percebe-se o viés de responsabilização administrativa, quando da irregularidade flagrada, com a lavratura de autuação, existe possibilidade de recorrer, seguindo as orientações de prazos e procedimentos para apresentação de defesa da autuação, do recurso contra notificações, e das penalidades atribuídas ao caso concreto.

\section{Polícia Federal}

Apesar de não estar a infração/crime ambiental expressamente descrita nas atribuições de persecução penal ambiental da Polícia Federal (PF), tal atribuição está prevista no art. 144, § 1ㅇ da Carta Magna e na Lei n. 10.446 de 2002, que dispõe sobre infrações penais de repercussão interestadual ou internacional que exigem repressão uniforme, para os fins do disposto no inciso I do §1을 do art. 144 da 
Constituição, quando se trata de um direito humano:

Art. 1․ Na forma do inciso I do $\S 10$ do art. 144 da Constituição, quando houver repercussão interestadual ou internacional que exija repressão uniforme, poderá o Departamento de Polícia Federal do Ministério da Justiça, sem prejuízo da responsabilidade dos órgãos de segurança pública arrolados no art. 144 da Constituição Federal, em especial das Polícias Militares e Civis dos Estados, proceder à investigação, dentre outras, das seguintes infrações penais:

[...]

III - relativas à violação a direitos humanos, que a República Federativa do Brasil se comprometeu a reprimir em decorrência de tratados internacionais de que seja parte;

O reforço teórico neste sentido, vem da lição de Lima (2019), quando afirma que "no caso de infrações penais de competência da Justiça Federal, a atribuição para realização das investigações incide sobre a Polícia Federal":

Afinal, de acordo com o art. 144, § 1으, I, primeira parte, da Constituição Federal, à Polícia Federal incumbe a apuração de infrações penais contra a ordem política e social ou em detrimento de bens, serviços, e interesses da União ou de suas entidades autárquicas e empresas públicas. Ademais, de acordo com o art. 144, § 1ㅇ, IV, da Carta Magna, cabe à

Polícia Federal exercer, com exclusividade, as funções de polícia judiciária da União.

Segundo Lima (2019), as atribuições da Polícia Federal (PF) são bem mais amplas que a competência da Justiça Federal, e assim, nem todo crime investigado pela Polícia Federal será julgado pela Justiça Federal. O autor, ressalta ainda que "por mais que a Emenda Constitucional n. 45/04 tenha introduzido na Constituição Federal o denominado incidente de deslocamento de competência, é oportuno lembrar que crimes cometidos com grave violação dos direitos humanos são, em regra, julgados pela Justiça Estadual”. 0 deslocamento de competência para a Justiça Federal deverá ser autorizado pelo Superior Tribunal de Justiça (STJ), quando ocorrer evidenciada desídia do aparato estadual em proceder a persecução penal.

Ao observar a lição de Lima (2019), tem-se que seja instaurado pela Polícia Civil (esfera estadual) ou pela Polícia Federal (esfera estadual ou federal), o inquérito será conduzido pelo Delegado de Polícia, como manda a Lei n. 13.047 de 2014. O art. 4ำ, parágrafo único, do CPP (Código de Processo Penal) não exclui os órgãos administrativos da investigação, quando diz de pleno vigor que "não excluirá a de autoridades administrativas, a quem por lei esteja cometida na mesma função".

\section{Ação e Processo Penal e o Papel do Ministério Público}

Todos os órgãos federais, bem como estaduais, municipais ou o Distrito Federal, bem como qualquer cidadão dotado do poder de polícia ambiental, deverão, nos termos do art. 129 da Carta Magna, em respeito à função institucional do Ministério Público, encaminhar-Ihe os inquéritos, denúncias e informações cabíveis para a tutela judicial do meio ambiente. O inciso III, do art. 129 da CF prevê que é função institucional do Ministério Público Federal ou Estadual, "promover o inquérito civil e a ação civil pública, para a proteção do patrimônio público e social, do meio ambiente e de outros interesses difusos e coletivos".

Conforme o art. 26 da Lei no 9.605/98, nas infrações penais previstas na referida lei, a ação penal é pública incondicionada. Atenção deve ser dada à necessidade de composição, herdada do art. 74 da Lei dos Juizados Especiais (Lei no 9.099/95), só que nesta feita a composição se dá em termos de danos ambientais, para que seja possível a proposta de aplicação da pena restritiva de direitos ou multa, previstos no art. 76 da 
mesma lei. $O$ art. 28 da Lei de Infrações Ambientais traz outras modificações herdadas da Lei de Juizados Especiais, nos incisos I ao V.

\section{CONSIDERAÇÕES FINAIS}

De uma análise da discussão e narrativa construídas nos capítulos deste trabalho conclui-se que os princípios que regem o Direito Penal Ambiental e o Direito Administrativo Ambiental estão bem definidos e articulados com demais ramos do direito. Observa-se que boa parte da doutrina nomina a Lei no 9.605/98 como de 'crimes ambientais', quando deveria nominá-la de Lei de Infrações Ambientais.

Os tipos penais previstos na Lei de Infrações Ambientais são normas penais em branco que dependem de resoluções do Conselho Nacional do Meio Ambiente, e de outras agências e organismos regulamentadores em cada nível de esfera de atuação. Alguns tipos são adaptações do próprio Código Penal, por exemplo, disseminação de doença e praga, ou os relacionados à corrupção de agentes públicos, gerando uma possível confusão de aplicação por parte do operador do direito.

Por fim, e então objeto maior deste estudo, tem-se clareza de que todos os órgãos policiais, sejam administrativos ou judiciários, nas esferas internacional, federal, estadual e/ou municipal, inclusive todas as pessoas, tem o dever de agir para combater os atos lesivos ao meio ambiente em sua mais ampla concepção. Tendo na esfera federal, objeto desta observação, o IBAMA, o ICMBIO, a Polícia Rodoviária Federal, e a Capitania dos Portos da Marinha do Brasil como agências federais administrativas, e a Polícia Federal como agência federal judiciária, todas aptas a isolada ou integradamente, oferecer denúncias e informações ao Ministério Público Estadual ou Federal, a depender das características da infração.

\section{REFERÊNCIAS}

ANTT. Agência Nacional de Transportes Terrestres. Resolução ANTT no 3.665 de 4 de maio de 2011. Atualiza o Regulamento para o Transporte Rodoviário de Produtos Perigosos. Brasília: DOU, 2011.

ANTT. Agência Nacional de Transportes Terrestres. Resolução ANTT no 5.232 de 14 de dezembro de 2016. Aprova as Instruções Complementares ao Regulamento Terrestre do Transporte de Produtos Perigosos, e dá outras providências. Brasília: DOU, 2016.

ANTT. Agência Nacional de Transportes Terrestres. Resolução ANTT no 5.848 de 25 de junho de 2019. Atualiza o Regulamento para o Transporte Rodoviário de Produtos Perigosos, revogando, a partir de 23 de dezembro de2019, a Resolução ANTT no 3.665/11. Brasília: DOU, 2019.

BITENCOURT, C. R.. Juizados especiais criminais e alternativas à pena de prisão. Porto Alegre: Livraria do Advogado, 1996.

BRASIL. Decreto-Lei 2.848 de 7 de dezembro de 1940. Código Penal. Rio de Janeiro: DOU, 1940.

BRASIL. Decreto-Lei 3.689 de 3 de outubro de 1941. Código de Processo Penal. Rio de Janeiro: DOU, 1941.
BRASIL. Lei 6.938, de 31 de agosto de 1981. Dispõe sobre a Política Nacional do Meio Ambiente, seus fins e mecanismos de formulação e aplicação, e dá outras providências. Brasília: DOU, 1981.

BRASIL. Constituição Federal. Brasília: DOU, 1988.

BRASIL. Lei $\mathbf{9 . 5 0 3}$ de $\mathbf{2 3}$ de setembro de 1997. Institui o Código de Trânsito Brasileiro. Brasília: DOU, 1997.

BRASIL. Lei 9.605 de 12 de fevereiro de 1998. Dispõe sobre as sanções penais e administrativas derivadas de condutas e atividades lesivas ao meio ambiente, e dá outras providências. Brasília: DOU, 1998a.

BRASIL. Mensagem de Veto 181. Vetos do Presidente da República à Lei no 9.605 de 1998. Brasília: DOU, 1998b.

BRASIL. Lei $\mathbf{1 0 . 4 4 6}$ de 2002. Dispõe sobre infrações penais de repercussão interestadual ou internacional que exigem repressão uniforme, para os fins do disposto no inciso I do §1ํ do art. 144 da Constituição. Brasília: DOU, 2002.

BRASIL. Lei 11.516, de 28 de agosto de 2007. Dispõe sobre a criação do Instituto Chico Mendes de Conservação da Biodiversidade - Instituto Chico Mendes; e dá outras providências. Brasília: DOU, 2007. 
BRASIL. Decreto 6.514 de 22 de julho de 2008. Dispõe sobre as infrações e sanções administrativas ao meio ambiente, estabelece o processo administrativo federal para apuração destas infrações, e dá outras providências. Brasília: DOU, 2008.

DALLARI, A. A.. Competência constitucional da Polícia Rodoviária Federal. Revista de Informação Legislativa, Brasília, v.34, n.135, p.253-260, 1997.

FRAGOSO, H. C.. Lições de Direito Penal. São Paulo: Bushatsky, 1958.

FREITAS, V. P.. A contribuição da lei dos crimes ambientais na defesa do meio ambiente. Revista CEJ, Brasília, n.33, p.515, 2006.

GUIMARÃES, D. T.. Dicionário técnico jurídico. 16 ed. São Paulo: Rideel, 2013.

IBAMA. Instrução Normativa no 10 de 7 de dezembro de 2012. Regula os procedimentos para apuração de infrações administrativas por condutas e atividades lesivas ao meio ambiente, a imposição das sanções, a defesa ou a impugnação, o sistema recursal e a cobrança de multa no âmbito do IBAMA. Brasília: DOU, 2012.

LECEY, E.. A proteção do meio ambiente e a responsabilidade penal da pessoa jurídica. In: FREITAS, V. P. Direito Ambiental em evolução. Curitiba: Juruá, 1998.
LIMA, R. B.. Legislação criminal especial comentada: volume único. 7 ed. Salvador: JusPODIVM, 2019.

MARCHESAN, A. M. M.; STEIGLEDER, A. M.. Crimes ambientais: comentários à Lei 9605/98. Porto Alegre: Livraria do Advogado, 2013.

MELLO, C. A. B.. Curso de Direito Administrativo. 34 ed. São Paulo: Malheiros Editores, 2019.

MILARÉ, É.. Direito do Ambiente. 11 ed. São Paulo: Revista dos Tribunais, 2018.

PRF. Polícia Rodoviária Federal. Instrução Normativa no 64 de 22 de dezembro de 2015. Dispõe sobre as informações mínimas que devem constar no auto de infração, prazos e procedimentos para apresentação da defesa de autuação e de recursos de penalidade de multa, por infrações ao Regulamento para Transporte Rodoviário de Produtos Perigosos. Brasília: DOU, 2015.

RAMOS, L. R.. Compendio de Derecho Penal. Madrid: Trivium, 1986

SIDOU, J. M. O.. Dicionário jurídico: Academia Brasileira de Letras Jurídicas. 11 ed. Rio de Janeiro: Forense, 2016.

SILVA, C. E.. Elaboração de TCC e publicação de artigos: for starters. Aracaju: Sustenere Publishing, 2018.

TOLEDO, F. A.. Princípios básicos de Direito Penal. São Paulo: Saraiva, 1982.

A CBPC - Companhia Brasileira de Produção Científica (CNPJ: 11.221.422/0001-03) detém os direitos materiais desta publicação. Os direitos referem-se à publicação do trabalho em qualquer parte do mundo, incluindo os direitos às renovações, expansões e disseminações da contribuição, bem como outros direitos subsidiários. Todos os trabalhos publicados eletronicamente poderão posteriormente ser publicados em coletâneas impressas sob coordenação da Sustenere Publishing, da Companhia Brasileira de Produção Científica e seus parceiros autorizados. Os (as) autores (as) preservam os direitos autorais, mas não têm permissão para a publicação da contribuição em outro meio, impresso ou digital, em português ou em tradução. 